\title{
In vitro biological activity of liposomal-containing antimony trioxide
}

\author{
Atividade biológica in vitro de lipossomas contendo trióxidlo de antimônio \\ Actividad biológica in vitro de liposomas que contienen trióxido de antimônio
}

Received: 08/23/2021 | Reviewed: 08/29/2021 | Accept: 09/01/2021 | Published: 09/05/2021

\author{
Altevir Rossato Viana \\ ORCID: https://orcid.org/0000-0002-0571-4219 \\ Universidade Franciscana, Brazil \\ E-mail: rossato.viana@hotmail.com \\ Angelita Bottega \\ ORCID: https://orcid.org/0000-0002-7168-7247 \\ Universidade Federal de Santa Maria, Brazil \\ E-mail: angelitabotega@yahoo.com.br \\ Marissa Bolson Serafin \\ ORCID: https://orcid.org/0000-0002-0044-6614 \\ Universidade Federal de Santa Maria, Brazil \\ E-mail: marissabolson@gmail.com \\ Bruno Salles \\ ORCID: https://orcid.org/0000-0002-4671-8726 \\ Universidade Franciscana, Brazil \\ E-mail: brunocsalles@live.com \\ Rosmari Horner \\ ORCID: https://orcid.org/0000-0002-5513-4853 \\ Universidade Federal de Santa Maria, Brazil \\ E-mail: rosmari.gmail@ufsm.br \\ Alexandre Krause \\ ORCID: https://orcid.org/0000-0001-8527-6601 \\ Universidade Federal de Santa Maria, Brazil \\ E-mail: alexandrekrause@ufsm.br \\ Luciana Maria Fontanari Krause \\ ORCID: https://orcid.org/0000-0001-8294-2533 \\ Universidade Federal de Santa Maria, Brazil \\ E-mail: Ifontanari@yahoo.com.br \\ Sergio Roberto Mortari \\ ORCID: https://orcid.org/0000-0002-1166-3980 \\ Universidade Franciscana, Brazil \\ E-mail: mortari@ufn.edu.br
}

\begin{abstract}
Antimonials are used as chemotherapy for leishmaniasis, but have limited results due to their toxicity and broad resistance already acquired by the parasites. Nanotechnology offers an alternative to reduce these effects through the use of biocompatible nanocarriers, which can be vectorized to the target site. In addition, the redirection of molecules, already developed for the treatment of other pathologies, has the advantage of being already approved for therapy by regulatory agencies. The present study addresses the production of liposomal vesicles containing antimony trioxide $\left(\mathrm{LC} \mathrm{Sb}_{2} \mathrm{O}_{3}\right)$, as well as the evaluation of activity against tumor and bacterial cells. We produce liposomes in order of nanometric size, polydispersity index (PDI <0.3), $\mathrm{pH}$ value close to physiological (7.2), and zeta potential (anionic). Cytotoxicity was evaluated in 24 and 72 hours, in the HepG2, T98G, and U87MG tumor cell lines, by the method (34.5 dimethylthiazole-2.5 diphenyltetrazolium bromide) (MTT). The minimum inhibitory concentration (MIC) was tested on three bacterial strains (American Type Culture Collection - ATCC-Escherichia coli ATCC 35218, Staphylococcus aureus ATCC 29213 and Enterococcus faecalis ATCC 29212) and mandatory (Staphylococcus aureus and Klebsiella pneumoniae). The liposomes were more cytotoxic than $\mathrm{Sb}_{2} \mathrm{O}_{3}$ in the free form, for all tested cell lines. This effect was stronger after 72 hours incubation. Antimony trioxide in both free and liposomal forms showed low antibacterial activity. Based on our results, we suggest that liposomes containing antimony trioxide have the potential for the repositioning of drugs addressing anticancer therapy.
\end{abstract}

Keywords: Bacteria; Cancer; Cell Line; Nanotechnology; Repositioning.

\section{Resumo}

Os antimoniais são utilizados como quimioterapia para leishmaniose, mas apresentam resultados limitados, devido a sua toxicidade e ampla resistência já adquirida pelos parasitas. A nanotecnologia oferece uma alternativa para reduzir esses efeitos por meio do uso de nanocarreadores biocompatíveis, que podem ser vetorizados. Além disso, o redirecionamento de moléculas, já desenvolvido para o tratamento de outras patologias, tem a vantagem de já ter sido 
aprovado para terapia pelos órgãos reguladores. O presente estudo aborda a produção de vesículas lipossomais contendo trióxido de antimônio $\left(\mathrm{LC} \mathrm{Sb}_{2} \mathrm{O}_{3}\right)$, bem como a avaliação da atividade contra células tumorais e bacterianas. Produzimos lipossomas na ordem de tamanho nanométrico, índice de polidispersidade (PDI <0,3), valor de $\mathrm{pH}$ próximo ao fisiológico $(7,2)$ e potencial zeta (aniônico). A citotoxicidade foi avaliada em 24 e 72 horas, nas linhagens tumorais HepG2, T98G e U87MG, pelo método (3-4,5 dimetiltiazol-2,5 difeniltetrazólio brometo) (MTT). A concentração inibitória mínima (CIM) foi testada em três cepas bacterianas (American Type Culture Collection ATCC-Escherichia coli ATCC 35218, Staphylococcus aureus ATCC 29213 e Enterococcus faecalis ATCC 29212) e obrigatória (Staphylococcus aureus e Klebsiella pneumoniae). Os lipossomas foram mais citotóxicos do que o $\mathrm{Sb}_{2} \mathrm{O}_{3}$ na forma livre, para todas as linhagens testadas. Este efeito foi mais forte após 72 horas de incubação. O trióxido de antimônio nas formas livre e lipossomal apresentou baixa atividade antibacteriana. Com base em nossos resultados, sugerimos que os lipossomas contendo trióxido de antimônio têm potencial para o reposicionamento de fármacos direcionados à terapia anticâncer.

Palavras-chave: Bacteria; Cancer; Linhagem Celular; Nanotecnologia; Reposicionamento.

\section{Resumen}

Los antimoniales se utilizan como quimioterapia para la leishmaniasis, pero tienen resultados limitados debido a su toxicidad y amplia resistencia ya adquirida por los parásitos. La nanotecnología ofrece una alternativa para reducir estos efectos mediante el uso de nanoportadores biocompatibles, que pueden ser vectorizados. Además, el redireccionamiento de moléculas, ya desarrollado para el tratamiento de otras patologías, tiene la ventaja de haber sido ya aprobado para terapia por organismos reguladores. El presente estudio aborda la producción de vesículas liposomales que contienen trióxido de antimonio $\left(\mathrm{LC} \mathrm{Sb}_{2} \mathrm{O}_{3}\right)$, así como la evaluación de su actividad frente a células tumorales y bacterianas. Producimos liposomas en el orden de tamaño nanométrico, índice de polidispersidad (PDI $<0.3$ ), valor de $\mathrm{pH}$ cercano al fisiológico (7.2) y potencial zeta (aniónico). La citotoxicidad se evaluó a las 24 y 72 horas, en las líneas tumorales HepG2, T98G y U87MG, por el método (bromuro de 3-4,5 dimetiltiazol-2,5 difeniltetrazolio) (MTT). La concentración mínima inhibitoria (MIC) se probó en tres cepas bacterianas (Colección Americana de Cultivos Tipo - ATCC-Escherichia coli ATCC 35218, Staphylococcus aureus ATCC 29213 y Enterococcus faecalis ATCC 29212) y obligatoria (Staphylococcus aureus y Klebsiella pneumoniae). Los liposomas fueron más citotóxicos que el $\mathrm{Sb}_{2} \mathrm{O}_{3}$ libre para todas las cepas ensayadas. Este efecto fue más fuerte después de 72 horas de incubación. El trióxido de antimonio en forma libre y liposomal mostró una baja actividad antibacteriana. Basándonos en nuestros resultados, sugerimos que los liposomas que contienen trióxido de antimonio tienen potencial para el reposicionamiento de fármacos destinados a la terapia contra el cáncer.

Palabras clave: Bacteria; Cáncer; Linaje celular; Nanotecnología; Reposicionamiento.

\section{Introduction}

Nanotechnology enables the manipulation of atoms and molecules to produce nanostructures, capable of interacting more and more with systems and media, aiming at solutions in important areas of society (Hornyak et al., 2008). Among the applicable areas, the nanomedicine, for therapy and diagnostics is one of the most important, in order to obtain drug products with more specific action with less adverse side effects (Klostergaard \& Seeney, 2012).

Liposomes are phospholipid structures that, in an aqueous medium, self-organize into bilayer structures, enabling the encapsulation of hydrophilic compounds inside and hydrophobic compounds between their lamellae (Gao et al., 2013). They are very promising as drug delivery systems, because these nanostructures have different characteristics compared to other drug delivery systems, including biocompatibility, absence of immunogenicity, self-assembly capacity, ability to load hydrophilic and hydrophobic agents, improving its solubility (Torchilin, 2005; Torchilin, 2007; Daeihamed et al., 2017).

The World Health Organization (WHO) reports that 12 million people are infected and 350 million people live in high-risk areas for leishmaniasis (Fernandez et al., 2018). Treatment with free antimonials has side effects and is already ineffective in some strains (Nilforoushzadeh et al., 2008).

Thus, it is possible to solubilize and encapsulate antimony trioxide $\left(\mathrm{Sb}_{2} \mathrm{O}_{3}\right)$, which allows greater control of its release, greater selectivity, and, mainly, a decrease in the toxicity of the compound (Loomis, Mcneeley, Bellankonda, 2011). Antimony compounds are the main active principles used to treat cutaneous leishmaniasis (Da-cruz \& Pirmez, 2005).

Considering the relevance to find new strategies to treat cancer and drug resistant microorganisms, drug repositioning and nanotechnology are important tools and should be explored. Thus, the present study evaluated the synergistic action of an 
antimonial compound combined with nanotechnology in a cell culture model. In addition, the antibacterial potential of these compounds was investigated using the minimal inhibitory concentration technique.

\section{Methodology}

\subsection{Production and characterization of liposome containing antimony trioxide ( $\left.\mathrm{LC} \mathrm{Sb}_{2} \mathrm{O}_{3}\right)$}

Although we have different liposome production methods (Mozafari et al., 2008), the reverse phase evaporation method was the method chosen for the production of liposomes in this work. The formulations were obtained according to Salles, 2019 with some adaptations. All chemicals were of analytical grade. To prepare $100 \mathrm{~mL}$ of liposome $0.8 \mathrm{~g}$ of phospholipids (Lipoid S100, Germany), $0.15 \mathrm{~g}$ cholesterol (Sigma-Aldrich, USA) and 0.02g of vitamin E were solubilized in $40 \mathrm{~mL}$ of ethyl acetate, with aid of ultrasonic bath for $10 \mathrm{~min}$ at a temperature of $25{ }^{\circ} \mathrm{C}$. Afterward, was added $0.025 \mathrm{~g}$ polysorbate 80 (Nuclear, Brazil), $4 \mathrm{~mL}$ of phosphate buffer $\mathrm{pH} 7.4$ containing 1,0 $\mathrm{mg} \mathrm{mL}^{-1}$ of antimony trioxide (Sb2O3, Merck, Germany), solubilized in tartaric ácid (Merck, Germany) 2.0 mol L-1. After mixing the phases, the solvent was extracted in rotavapor (Rotavapor BUCHI ${ }^{\circ}$, Switzerland) to $40{ }^{\circ} \mathrm{C}$ for removing the organic solvent and forming the organogel. To obtain better homogeneity, the formulation was sonicated (Vibra-Cell VCX 750, Titanium Probe, Sonics \& Materials Inc., USA) at a power of $750 \mathrm{~W}, 40 \%$ amplitude, at 8 minutes with cycles of $8 \mathrm{~s}$ on and $2 \mathrm{~s}$ off. The formulation remained stable for up to 30 days when stored in the refrigerator.

\subsubsection{Stability of liposomes}

$\mathrm{pH}$ was measured with the potentiometer DM-22 (Digimed, Brazil), previously calibrated with standard solutions of pH 4.0 and 7.0. For physico-chemical characterizations, the liposomes were determined by dynamic light scattering, using a Zetasizer ZS® (Malvern Instruments, UK), using the software Dispersion Technology v5.1. The measurements were performed in triplicate. For determining the average particle diameter, the formulations were diluted 500 times (v/v) in purified water (Milli-Q®). Already for the determination of the zeta potential, the formulations were dispersed in $\mathrm{NaCl} 10 \mathrm{mmol} \mathrm{L}^{-1}$.

\subsection{Cell culture}

The tumor cell lines chosen were HepG2 (hepatocarcinoma) and U87MG and T98G (glioblastomas). The cells were grown in polystyrene $25 \mathrm{~cm}^{2}$ bottles with Dulbecco's Modified Eagle Medium (DMEM) (Sigma-Aldrich) medium, supplemented with $10 \%$ fetal bovine serum and 1\% penicillin/streptomycin (Sigma-Aldrich) in a humidified incubator with 5\% $\mathrm{CO} 2$ at $37^{\circ} \mathrm{C}$ (Laboven). For the experiment, the cells were transferred into 96-well (Kasvi) flat-bottom plates at a concentration of $1 \times 10^{4}$ per well. After 24 hours in the $\mathrm{CO}_{2}$ incubator for adherence, the medium was changed and treatments were added in the concentrations of 50, 100, 250, and $500 \mu \mathrm{g} \cdot \mathrm{mL}^{-1}$ of $\mathrm{Sb}_{2} \mathrm{O}_{3}$ in the free form and liposomes-containing $\mathrm{Sb}_{2} \mathrm{O}_{3}$ ( $\mathrm{LC} \mathrm{Sb}_{2} \mathrm{O}_{3}$ ). The test performed to check cytotoxicity was (3-4,5 dimethylthiazol-2,5 diphenyltetrazoliumbromide) (MTT) (Sigma-Aldrich) for periods of 24 and 72 hours. In the positive control, hydrogen peroxide was added at a concentration of 100 mmol L-1 (Godoi et al., 2017), and the negative control contained only cells and culture medium.

\subsubsection{MTT Colorimetric Assay}

Cell viability was assessed by the activity of dehydrogenases using the 3- (4,5-dimethylthiazol-2-yl) -2,5diphenyltetrazolium (MTT) bromide salt reduction assay in a product insoluble in blue-purple water called formazan. After the incubation periods, $20 \mu \mathrm{L}$ of the reagent at a concentration of $5 \mathrm{mg} \cdot \mathrm{mL}^{-1}$ was added to each well containing cells staying in the $\mathrm{CO}_{2}$ incubator for 4 hours. Finally, the supernatant was removed and the product accumulated inside the cell was extracted by adding DMSO (Synth) (Mosmann, 1983). Reading was done on an ELISA machine at $570 \mathrm{~nm}$. 


\subsection{Evaluation of antibacterial activity in vitro}

\subsubsection{Bacterial strains}

The evaluation of antibacterial activity in vitro was performed against five bacterial strains: three reference standards from the American Type Culture Collection (ATCC) collection and two clinical isolates resistant to multiple drugs (MDR). The strains were stored in TSB broth (TrypticSoyBroth) containing $15 \%$ glycerol at $-20^{\circ} \mathrm{C}$. The ATCC strains used were: S. aureus ATCC 29213, E.coli ATCC 35218 and E. faecalis ATCC 29212.

The MDR isolates selected for the study were obtained from patients admitted to a university hospital, as follows: S.aureus and K.pneumoniae, which were identified through manual and automated phenotypic tests using the Vitek® 2 device (BioMérieux, MarcyI'Etoile, France), at the Microbiology Laboratory of that hospital, and assigned to carry out the experiments.

\subsubsection{Determination of the minimum inhibitory concentration}

The minimum inhibitory concentration (MIC), defined as the lowest concentration of the compound that prevents visible growth of the microorganism, was determined by the standard broth microdilution method, following document M7-A9 of the Clinical and Laboratory Standards Institute, 2012 (CLSI).

At the same time, MIC was determined for antimony trioxide and liposomes containing antimony trioxide. The concentrations tested for the compounds were in the range of $0.25-256 \mu \mathrm{g} \mathrm{mL}^{-1}$. The bacterial inoculum was prepared in sterile saline using the method of direct suspension of colonies from recent cultures. The reference for the turbidity of the bacterial suspension was the $0.5 \mathrm{McFarland}$ standard, that is, 1 to $2 \times 10^{8}$ colony-forming units / $\mathrm{mL}$ (CFU / mL). Briefly, 96-well microplates, containing Mueller Hinton broth, the test compounds, and bacterial inoculum ( 1 x $10^{5} \mathrm{UFC} /$ well), were incubated at $35 \pm 2{ }^{\circ} \mathrm{C}$ for 24 hours. After the incubation period, the MIC was determined by visual reading. In addition to determining the MIC of the compounds, other controls employed in the assay were: growth control of the bacterial inoculum (culture medium + inoculum) and sterility control of the culture medium (culture medium only). All tests were performed in triplicate.

The Research and Ethics Committee under CAAE 38850614.4.0000.5346 approved the use of isolates for clinical research. Their choice for inclusion in the study is due to their clinical relevance. The registration in the National System for the Management of Genetic Heritage and Associated Traditional Knowledge (SisGen) is registered under number AE78E18 Federal University of Santa Maria, Santa Maria, RS, Brazil.

\subsection{Statistical Analysis}

The statistical analysis was performed with the help of the GraphPad Prism program, using the one-way ANOVA methodology, followed by Tukey's post hoc test, comparing the treatments with the negative control. Values with $\mathrm{p}<0.05$ were considered statistically significant. Being * $\mathrm{p}<0.05$; ** $\mathrm{p}<0.01$; *** $\mathrm{p}<0.001$.

\section{Results and Discussion}

Antimony is a natural element used for over 100 years with remarkable efficacy in patients with acute promyelocytic leukemia (Sharma et al., 2008). Trivalent antimony was reported for the treatment of cutaneous leishmaniasis by Vianna in 1913 and its effectiveness was confirmed by Di Cristina and Caronia (1915).

A large number of metal complexes exhibit a pronounced antitumor effect, which makes them of high interest for applications in the treatment of different types of cancer (Desoize, 2004).seria interessante colocar referências mais atuais.

The use of existing drugs but with a new repositioning, does not need the first six to nine years, included for development, and can go directly to pre-clinical and clinical tests, costs and risks (Ashburn; Thor, 2004). 
For therapeutic use, liposomal vesicles should have an average particle size below $500 \mathrm{~nm}$ (intravenous formulation limit), PDI <0.3 (homogeneity), and non-zero zeta potential (confer colloidal stability) (Mohanrajet al., 2006; Zhang et al., 2010; Chen et al., 2015; Lowry et al., 2016; Rodrigues; Lemma 2014). Here, these conditions were pre-established and obtained using a reverse-phase method with the assistance of ultrasonic radiation, for homogenization of the liposomal vesicles (Table 1).

Table 1 -Characterization of liposome containing antimony trioxide - $\mathrm{LC} \mathrm{Sb}_{2} \mathrm{O}_{3}, \mathrm{n}=3$.

\begin{tabular}{cc}
\hline Parameter & Results \\
\hline size $(\mathrm{nm})$ & $80.21 \pm 5.6$ \\
PDI & $0.280 \pm 0.04$ \\
Zeta $(\mathrm{mV})$ & $-6.4 \pm 0.88$ \\
$\mathrm{pH}$ & $7.66 \pm 0.36$ \\
Active content $\left(\mathrm{mg} \mathrm{mL}^{-1}\right)$ & $0.988 \pm 0.002^{*}$ \\
\hline
\end{tabular}

Source: Authors.

In the HepG2 cell line (Figure 1), in 24 hours of incubation, treatment with $\mathrm{LC} \mathrm{Sb}_{2} \mathrm{O}_{3}$, at concentrations of 100, 250 , and $500 \mu \mathrm{g} \mathrm{mL} \mathrm{m}^{-1}$ decreased viability to $72 \%, 30.3 \%$, and $20.3 \%$, respectively. In contrast, $\mathrm{Sb}_{2} \mathrm{O}_{3}$, in its free form, was statistically different $\mathrm{p}<0.001$ to the control only in the two highest concentrations of 250 and $500 \mu \mathrm{g} \mathrm{mL} \mathrm{L}^{-1}$, with low viability to $53.6 \%$ and $42.3 \%$. In contrast, in the 72 hours, all concentrations tested were cytotoxic, especially $\mathrm{LC} \mathrm{Sb}_{2} \mathrm{O}_{3}$, which was close to the positive control $\left(\mathrm{H}_{2} \mathrm{O}_{2}\right)$. In this study, a better cytotoxic activity of $\mathrm{LC} \mathrm{Sb}_{2} \mathrm{O}_{3}$ vesicles was observed in front of tumor lines, than their free form. Relevant facts, therefore, can provide a more advantageous therapy to patients, due to the characteristics of the liposomes. The application of nanotechnology is highly anticipated for the pharmaceutical and biotechnological scenario (Whitesides, 2003; Lavan; Mcguire, Langer, 2003; Ferrari, 2005). One of the most widely used drug carriers is liposomes (Bangham, Standish, Watkins, 1965), as in anticancer therapies, infectious and parasitic diseases (Daraee et al., 2016). Among the benefits of using liposomes, is the ability to overcome the limitations of conventional chemotherapy, improving the bioavailability and stability of the drug's molecules and, minimizing side effects, by direct delivery to the site of interest (Pandey, Rani, Agarwal, 2016). This targeted delivery also circumvents an undesirable effect of redirection, due to the low potency of some compounds, which would end up limiting their immediate clinical applications, due to their tolerated plasma concentrations, being lower than the necessary therapeutic concentrations (Sun, Sanderson, Zheng, 2016) GLC4 cells that contained overexpression of MRP1, which is a drug resistance gene, showed that there were far fewer Sb (III) molecules than in those that did not have this transfection. In this way, nanotechnology could contribute to circumvent this barrier, caused by the aforementioned gene. 
Figure 1 - Assessment of cytotoxicity in the Hepg2 cell line
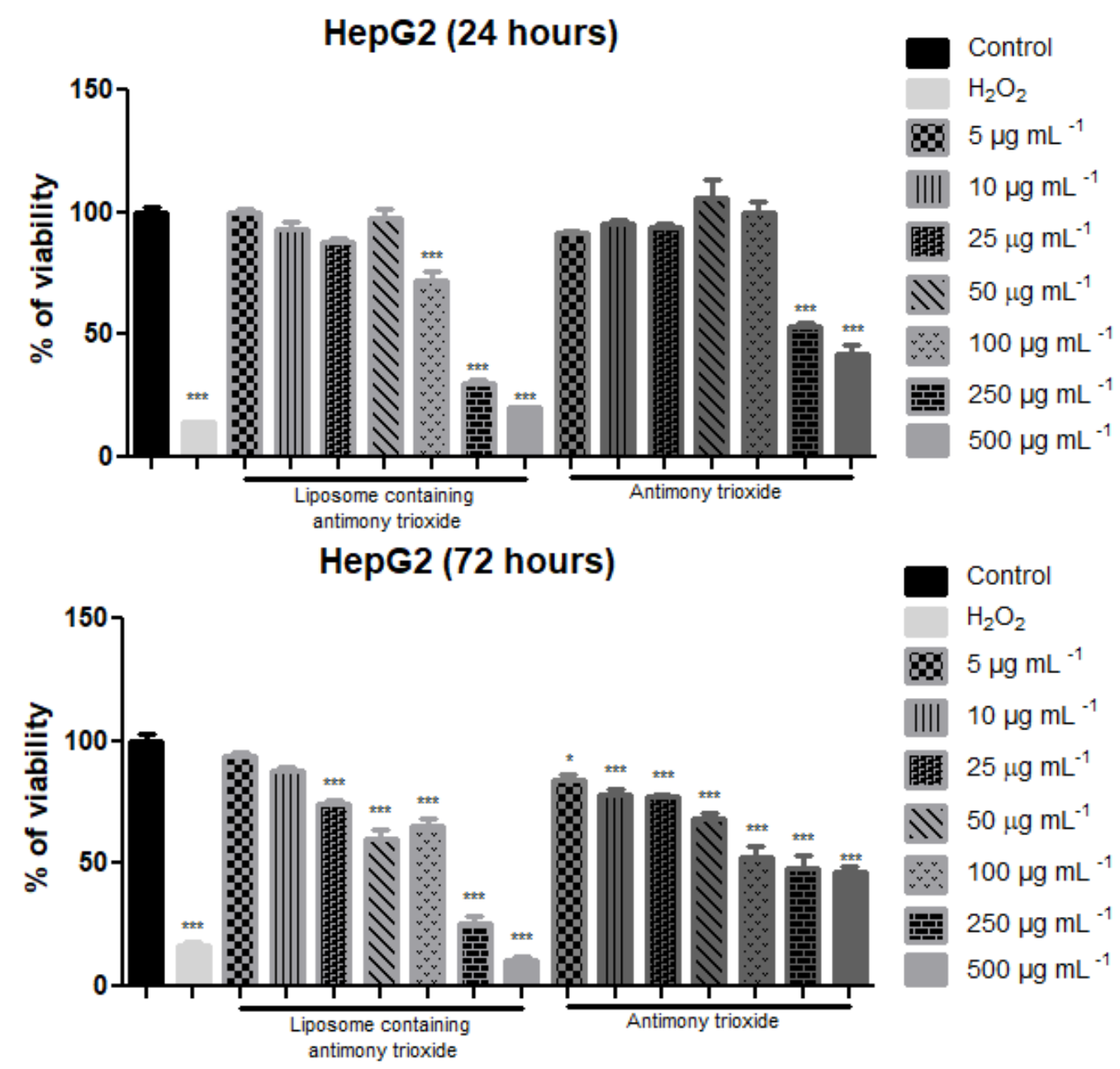

Evaluation of cytotoxicity in the HepG2 tumor line through the colorimetric assay (MTT) in 24 hours (A) and 72 hours (B). Negative control (cells + culture medium); positive control (100 mmol L-1 $\left.\mathrm{H}_{2} \mathrm{O}_{2}\right)$; Liposome containing antimony trioxide; antimony trioxide. The analyzes were followed by one-way ANOVA, followed by Tukey's post hoc test, comparing the treatments with the negative control. Values with $\mathrm{p}<0.05$ were considered statistically significant. Being $\mathrm{p}<0.05 * ; \mathrm{p}<0.01$ $* * ; \mathrm{p}<0.001 * * *$. Source: GraphPad Prism.

Like the previous cell line, T98G cells (Figure 2) showed sensitivity in the 3 highest concentrations of $\mathrm{LC} \mathrm{Sb}_{2} \mathrm{O}_{3}$, reducing viability to about $69.9 \%, 9.6 \%$, and $5.3 \%$. Antimony in the free form also caused cytotoxicity, more significant in the two highest concentrations, approaching the results obtained with the liposomal form. In 72 hours of incubation, both treatments were more cytotoxic but more evident in $\mathrm{LC} \mathrm{Sb}_{2} \mathrm{O}_{3}$. The concentration of $500 \mu \mathrm{g} \mathrm{mL}^{-1}$ had a greater decrease in the number of cells than the positive control itself. Changing the chemical conformation and/or perhaps the way a drug will enter or act on cells is of fundamental importance, since Sb (III) had apoptotic effects in the lines CCRF-CEM, HL-60, K-562, and LOUCY, however, when modulators of the cellular redox system were added, it provided protection concerning the activity of the trivalent antimony (Losler et al., 2009). 
Figure 2 - Assessment of cytotoxicity in the T98G cell line.
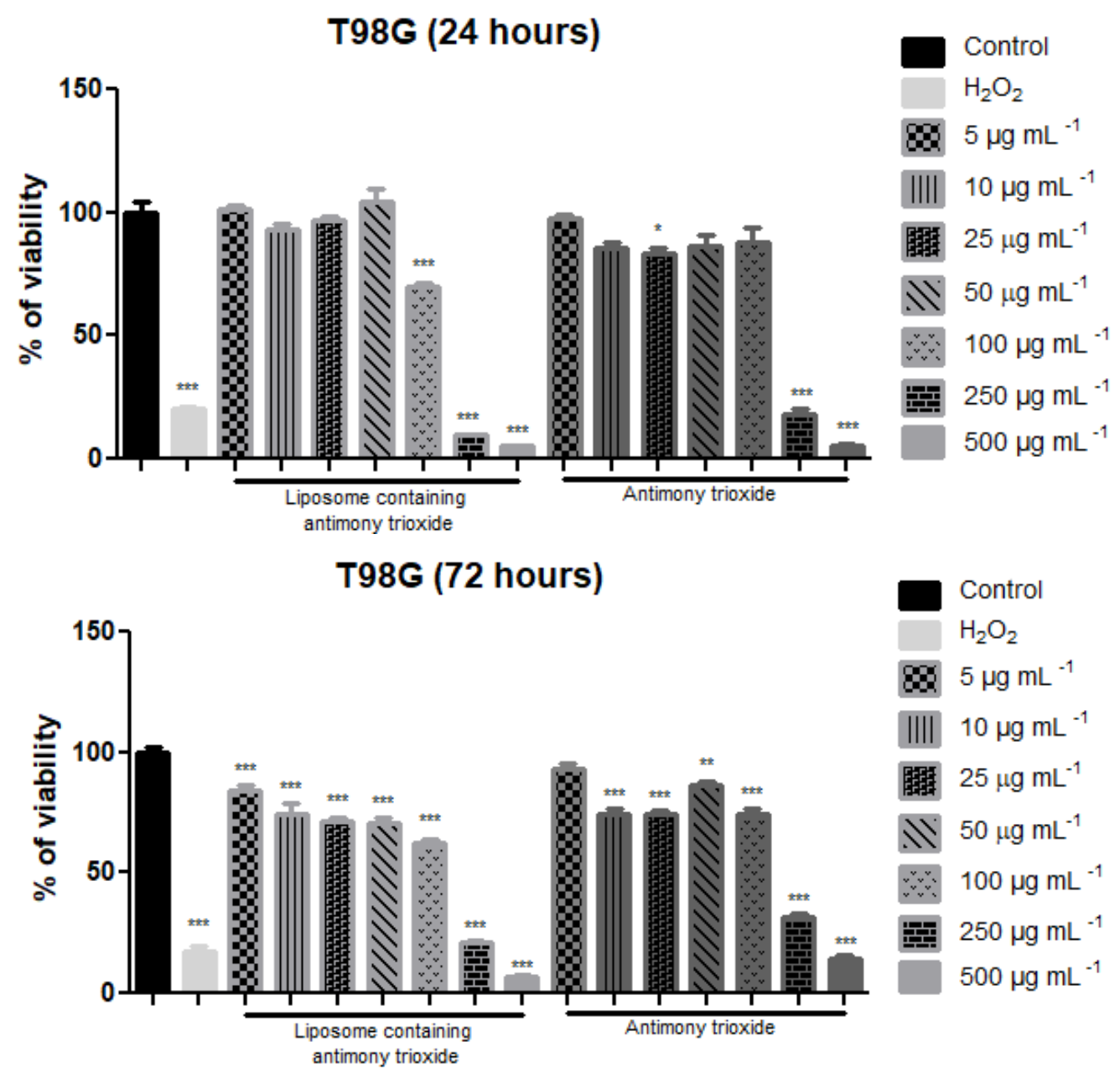

Evaluation of cytotoxicity in the T98G tumor line through the colorimetric assay (MTT) in 24 and 72 hours. Negative control (cells + culture medium); positive control (100 mmol ${ }^{\mathrm{L}-1} \mathrm{H}_{2} \mathrm{O}_{2}$ ); Liposome containing antimony trioxide; antimony trioxide. The analyzes were followed by one-way ANOVA, followed by Tukey's post hoc test, comparing the treatments with the negative control. Values with $\mathrm{p}<0.05$ were considered statistically significant. Being $\mathrm{p}<0.05 * ; \mathrm{p}<0.01 * * ; \mathrm{p}<0.001 * * *$. Source: GraphPad Prism.

The U87MG strain (Figure 3) was the one that showed the most significant results concerning the cytotoxicity of LC $\mathrm{Sb}_{2} \mathrm{O}_{3}$, this result was also seen in the study by Zhang et al. (2015) when compared to the HepG2 strain treated with new chemical synthesis. From $25 \mu \mathrm{g} \mathrm{mL} \mathrm{mL}^{-1}$, the concentrations used were between $23 \%$ and $5 \%$ viability. In 24 hours, at concentrations between $5-100 \mu \mathrm{g} \mathrm{mL} \mathrm{L}^{-1}$, antimony in its free form obtained results similar to the negative control. In the two highest concentrations ( 250 and $500 \mathrm{~mL}^{-1}$ ), they presented cytotoxicity. In contrast, after 72 hours of incubation, the results of LC $\mathrm{Sb}_{2} \mathrm{O}_{3}$ remained similar, and the antimony in its free form decreased cell viability in treatments that had not been toxic previously, except in $5 \mu \mathrm{g} \mathrm{mL}^{-1}$.

Liposomes loaded with different drugs were able to significantly decrease the number of cells, more than the free form in breast cancer strains (MCF-7) and ovarian cancer (A2780CP) (Sharma, Kumar, 2017; Shirzad et al., 2016 ). In another study, this same nanocarrier showed a greater amount of doxorubicin accumulated inside colon tumor cells, causing a constant release of the drug after its entry (Oudard et al., 1991). This prolonged-release must be the reason for the greater cytotoxicity found in 72 hours in tumor cells, and not be as effective in the 24 hours of MIC incubation. 
Figure 3 -Assessment of cytotoxicity in the U87MG cell line.
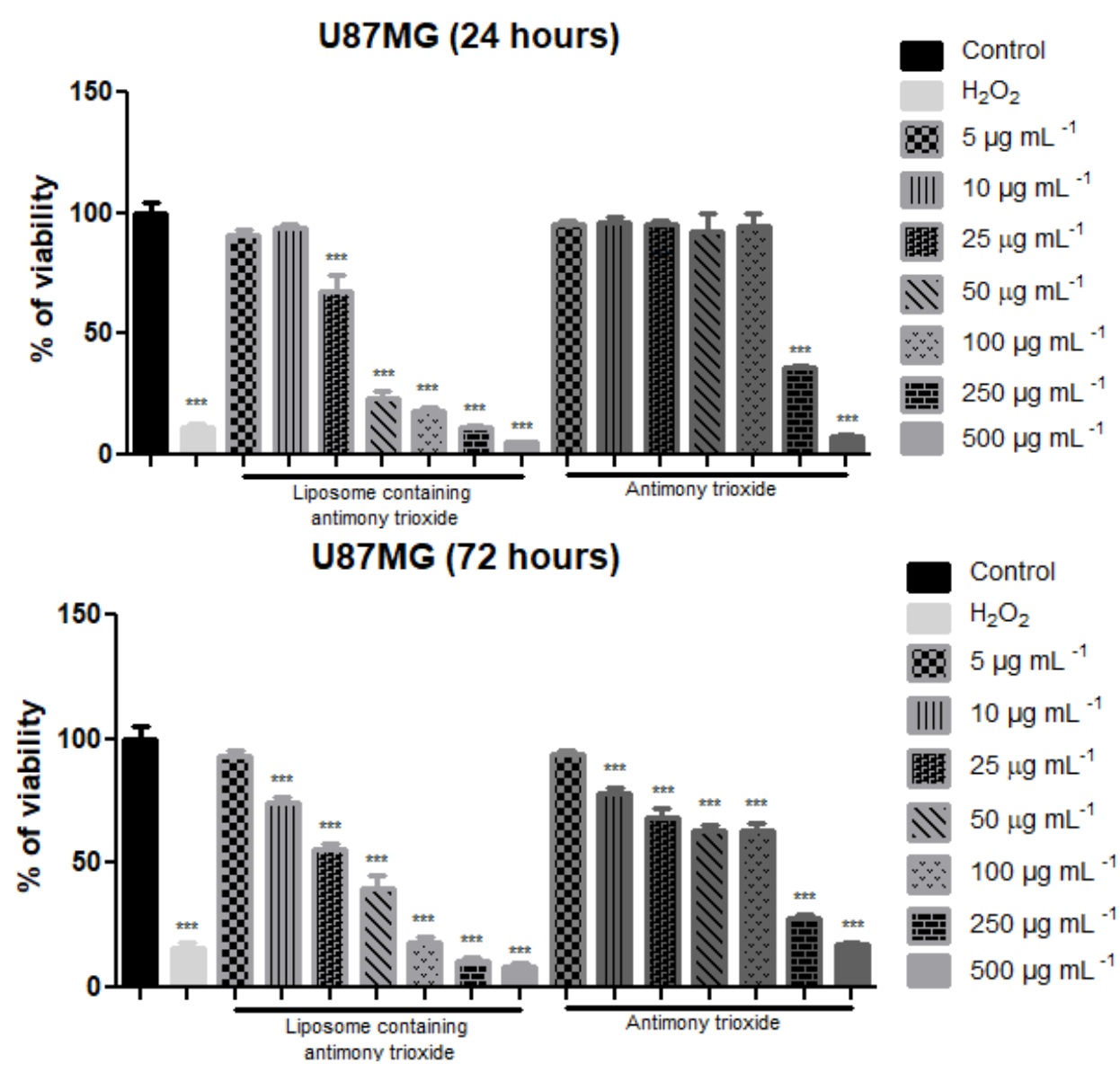

Evaluation of cytotoxicity in the U87MG tumor line through the colorimetric assay (MTT) in 24 and 72 hours. Negative control (cells + culture medium); positive control $\left(100 \mathrm{mmol}^{\mathrm{L}-1} \mathrm{H}_{2} \mathrm{O}_{2}\right)$; Liposome containing antimony trioxide; antimony trioxide. The analyzes were followed by one-way ANOVA, followed by Tukey's post hoc test, comparing the treatments with the negative control. Values with $\mathrm{p}<0.05$ were considered statistically significant. Being $\mathrm{p}<0.05 * ; \mathrm{p}<0.01 * * ; \mathrm{p}<0.001^{* * *}$. Source: GraphPad Prism.

In Table 2 it is possible to check the IC50 values at different times in the different cell lines obtained through the MTT test referring to the previous graphics.

Table 2 - Necessary concentration of different treatments to inhibit $50 \%$ of cells.

\begin{tabular}{|c|c|c|c|c|}
\hline \multirow{3}{*}{ Cell line } & \multicolumn{4}{|c|}{$\mathrm{IC}_{50} \mu \mathrm{g} \mathrm{mL}^{-1}$} \\
\hline & \multicolumn{2}{|c|}{24 hours treatment } & \multicolumn{2}{|c|}{72 hours treatment } \\
\hline & $\mathrm{LC} \mathrm{Sb}_{2} \mathrm{O}_{3}$ & $\mathrm{Sb}_{2} \mathrm{O}_{3}$ & $\mathrm{LC} \mathrm{Sb}_{2} \mathrm{O}_{3}$ & $\mathrm{Sb}_{2} \mathrm{O}_{3}$ \\
\hline HepG2 & 184.02 & 394.18 & 98.58 & 352.97 \\
\hline T98G & 158.32 & 216.28 & 134.25 & 210.42 \\
\hline U87MG & 22.13 & 21.40 & 33.29 & 241.15 \\
\hline
\end{tabular}

Source: Authors.

Table 3 shows the MIC values obtained from antimony trioxide and liposomes containing this compound, where the only inhibitory activity of free trioxide is observed ( $\mathrm{MIC}=128 \mu \mathrm{g} \mathrm{mL} \mathrm{m}^{-1}$ and $256 \mu \mathrm{g} \mathrm{mL}^{-1}$ ). of anticancer activity, there are reports in the literature that liposomes have been used successfully as carriers of antimicrobial agents in bacterial, protozoan, 
fungal models and in viral infections (Bakker et al., 1993; Bakker et al., 1995; Webb et al., 1998). Studies suggest that the use of these molecules with drugs can increase the therapeutic efficacy by the selective delivery of agents to infected tissues and reduce the toxicity of potentially toxic substances (Bakker et al., 1993; Vanicet al., 2019). Thus, we evaluated the antibacterial activity of our compounds, against standard bacterial strains of reference and relevant clinical isolates.

From the results obtained in the in vitro test, a low antibacterial activity was observed, exerted both by the antimony

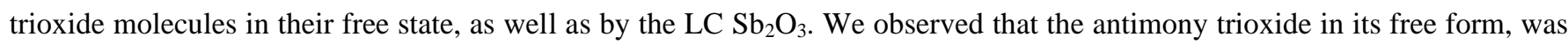
more active concerning the encapsulated liposomes against the strains of $S$. aureus ATCC $29213\left(\mathrm{CIM}=128 \mu \mathrm{g} \mathrm{mL}^{-1}\right)$ and $E$. faecalis ATCC $29212\left(\mathrm{CIM}=128 \mu \mathrm{g} \mathrm{mL}^{-1}\right)$, as well as against the $K$. pneumoniae isolate $\left(\mathrm{MIC}=128 \mu \mathrm{g} \mathrm{mL}^{-1}\right)$. This difference in results may have occurred because liposomes need a longer time for degradation to occur if their lipid membrane and thus can be released, which may not have occurred entirely during the incubation period, with the strains analyzed, which requires further investigation of this possible activity.

Table 3 - In vitro antibacterial activity of antimony trioxide and liposomes against the ATCC reference standard and isolates.

\begin{tabular}{|c|c|c|c|}
\hline Strains ATCC & $\begin{array}{c}\text { Escherichia } \\
\text { coli } 35218\end{array}$ & $\begin{array}{c}\text { Staphylococcus } \\
\text { aureus } 2913\end{array}$ & $\begin{array}{r}\begin{array}{c}\text { Enterococcus } \\
\text { faecallis } 29212\end{array} \\
\end{array}$ \\
\hline MIC & $\left(\mu \mathrm{g} \mathrm{mL}^{-1}\right)$ & $\left(\mu \mathrm{g} \mathrm{mL}^{-1}\right)$ & $\left(\mu \mathrm{g} \mathrm{mL}^{-1}\right)$ \\
\hline $\mathrm{Sb}_{2} \mathrm{O}_{3}$ & $=256$ & $=128$ & $=128$ \\
\hline $\mathrm{LC} \mathrm{Sb}_{2} \mathrm{O}_{3}$ & $>256$ & $>256$ & $>256$ \\
\hline $\begin{array}{c}\text { Clinical Isolates } \\
\text { MDR }\end{array}$ & $\begin{array}{c}\text { Staphylococcus } \\
\text { aureus }\end{array}$ & & $\begin{array}{c}\text { Klebsiella } \\
\text { pneumoniae }\end{array}$ \\
\hline MIC & $\left(\mu \mathrm{g} \mathrm{mL}^{-1}\right)$ & & $\left(\mu \mathrm{g} \mathrm{mL}^{-1}\right)$ \\
\hline $\mathrm{Sb}_{2} \mathrm{O}_{3}$ & $=256$ & - & $=128$ \\
\hline $\mathrm{LC} \mathrm{Sb}_{2} \mathrm{O}_{3}$ & $>256$ & - & $>256$ \\
\hline
\end{tabular}

Source: Authors.

\section{Conclusion}

Liposomes containing antimony trioxide produced using the reverse phase evaporation method, followed by the use of ultrasound, showed an adequate characterization to be able to enter eukaryotic and prokaryotic cells. The most significant results of cell death were found in tumor cells after 72 hours than in ATCC strains and clinical isolates, probably due to the lack of time to release the active substance during the trial period. Future prospects will be to expand the number of tests on cell lines as they showed better effects. In addition to the use of in vivo tumor models.

\section{Acknowledgments}

This study was supported in part by the Coordenação de Aperfeiçoamento de Pessoal de Nível Superior - Brasil (CAPES) - Finance Code 001.

\section{References}

Ashburn, T. \& Thor, K. (2004), Drug repositioning: identifying and developing new uses for existinf drugs. Nat Rev Drug Discov, 3 , $673-683$.

Bakker-Woudenberg, I. A. J. M., Lokerse, A. F., ten Kate, M. T., Mouton, J. W., Woodle, M. C. \& Storm, G. (1993). Liposomes with prolonged blood circulation and selective localization in Klebsiella pneumoniae-infected lung tissue. Int J Infect Dis, 168,164-71.

Bakker-Woudenberg, I.A., ten Kate, M.T., Stearne-Cullen, L.E.T., Woodle, M. C. (1995). Efficacy of gentamicin or ceftazidime entrapped in liposomes with prolonged blood circulation and enhanced localization in Klebsiella pneumoniae. Int J Infect Dis, 171, 938-947.

Bangham, A., Standish, M., Watkins, J. (1965). Diffusion of univalent ions across the lamellae of swollen phospholipids. J Mol Biol, 1, $238-252$. 
Chen, H., Wang, Y., Zhai, Y., Zhai, G., Wang, Z., Liu, J. (2015). Development of a ropivacaine-loaded nanostructured lipid carrier formulation for transdermal delivery. Colloids Surfaces A Physico chem Eng Asp, 465,130-136.

Da-Cruz A M. \& Pirmez, C. (2015). Leishmaniose tegumentar americana. In: Coura JR, editor. Dinâmica das doenças infecciosas e parasitárias. (1a ed.).

Daeihamedet, M., Dadashzadeh, S., Haeri, A., Akhlaghi, M. (2017). Potential of liposomes for enhancement of oral drug absorption. Curr Drug Deliv, 14, 289-303.

Daraee, H., Etemadi, A., Kouhi, M., Alimirzalu, S., Akbarzadeh, A. (2016). Application of liposomes in medicine and drug delivery. Artif Cells Nanomed Biotechnol, 44, 381-391.

Desoize, B. Metais e compostos metálicos no tratamento do câncer. (2004). Anticancer Res, v.24; 1529-1535.

Di Cristina, G. \& Caronia, G. (1915). Sulla terapia del la leishmaniose interna. Pathologica, 7, 82-83.

Fernandez, M., Murillo, J., Ríos-Vásquez, L.A., Ocampo-Cardona, R., Cedeño, D.L., Jones, M.A., Velez, I.D., Robledo, S.M. (2018). In vivo studies of the effectiveness of novel $\mathrm{N}$-halomethylated and non-halomethylated quaternary ammonium salts in the topical treatment of cutaneous leishmaniasis. Parasitol. Res, 117(1), 273-286.

Ferrari, M. (2005). Cancer Nanotechnology: Opportunities and Challenges. Nat Rev Cancer, 5, 161-171.

Gao, W., Hu, C., Fang, R., Zhang, L. (2013). Liposome-like nanostructures for drug delivery. J Mater Chem B, 1(48), 6569-6585.

Godoi, S. N., Quatrin, P. M., Sagrillo, M. R., Nascimento, K., Wagner, R., Klein, B., Santos, R. C. V., Ourique, A. F. (2017). Evaluation of stability and in vitro security of nanoemulsions containing Eucalyptus globulus oil. Biomed Res Int, 2723418.

Hornyak, G., Tibbals, H., Dutta J., Moore, J. (2008). Introduction to nanoscience and nanotechnology, $1^{\text {st }}$ Edition, Boca Raton, Londes, CRC press.

Klostergaard, J. \& Seeney, C. E.(2012). Magnetic nanovectors for drug delivery.Nanomedicine: NBM, 8, 37-50.

LaVan, D. A., McGuire, T., Langer, R. (2003). Small-Scale Systems for in vivo Drug Delivery. Nat. Biotechnol, $21,1184-1191$.

Loomis, K., Mcneeley, K., Bellamkonda, R. V. (2011). Nanoparticles with targeting, triggered release, and imaging functionality for cancer applications. Soft Matter, 7, 839-856.

Losler, S., Schlief, S., Kneifel, C., Thiel, E., Schrezenmeier, H., Rojewski, M. (2009). Antimony-trioxide- and arsenic-trioxide-induced apoptosis in myelogenic and lymphatic cell lines, recruitment of caspases, and loss of mitochondrial membrane potential are enhanced by modulators of the cellular glutathione redox system. Ann Hematol, 88, 1047-1058.

Lowry, G. V., Hill., R.J, Harper, S., Rawle, A.F., Hendren, C.O., Klaessig, F., Nobbmann, U., Sayre, P., Rumble, J. (2016). Guidance to Improve the Scientific Value of Zeta Potential Measurements in nano EHS. Environ Sci Nano, 3, 953-965.

Mohanraj, V., Chen, Y., Chen, M. (2006) Nanoparticles - A Review. Trop J Pharm Res, 5, 561-73.

Mosmann, T. Rapid colorimetric assay for cellular growth and survival: Application to proliferation and cy totoxicity assays. (1983) J Immunol Methods, 65, 55-63.

Mozafari, M. R., Johnson, C., Hatziantoniou, S., Demetzos, C. (2008). Nanoliposomes and their applications in food nanotechnology. J Liposome Res, 18(4), 309327.

Nilforoushzadeh, M.A., Shirani-Bidabadi, L., Zolfaghari-Baghbaderani, A., Saberi, S., Siadat, A.H., Mahmoudi, M. (2008). Comparison of Thymus vulgaris (Thyme), Achillea millefolium (Yarrow) and propolis hydroalcoholic extracts versus systemic glucantime in the treatment of cutaneous leishmaniasis in balb/c mice. J. Vector Borne Dis, 45(4), 301-306.

World Health Organization. [citad 2020]. Available in: https://www.who.int/health-topics/cancer\#tab=tab_1

World Health Organization. [citad 2019] Available in: https://apps.who.int/iris/bitstream/handle/10665/330420/9789240000193-eng.pdf

Oudard, S., Thierry, A., Jorgensen, T., Rahman, A. (1991) Sensitization of multidrug-resistant colon cancer cells to doxorubicin encapsulated in liposomes. Cancer Chemother Pharmacol, 28:259-265.

Pandey, H., Rani, R., Agarwal, V. (2016). Liposome and Their Applications in Cancer Therapy. Braz Arch Biol Technol, 59, 1-10.

Rodrigues, M.I. \& Lemma, A.F. (2014). Planejamento de experimentos e otimização de processos. 3rd ed.

Salles, BC. Desenvolvimento e caracterização de vesículas lipossomais contendo trióxido de antimônio sintetizadas via energia ultrassônica. Dissertação de mestrado. Santa Maria/RS, Universidade Franciscana - UFN, 2019.

Sharma, P., Diego, Perez., Armando, C., Noe, R., Jose, LA. (2008). Perspectives of antimony compounds in oncology.Acta Pharmacol Sin, 29, 881-890.

Sharma, S., Kumar, V. (2017). In vitro cytotoxicity effect on mcf-7 cell line of co-encapsulated artesunate and curcumin liposome. $J$ Pharm, 9 , 123.

Shirzad, M., Jamehbozorgi, S., Akbarzadeh, A., Aghabozorg, H. (2016).Cytotoxicity of nanoliposomal cisplatin coated with synthesized methoxypolyethylene glycol propionaldehyde in human ovarian cancer cell line A2780CP.Trop J Pharm Res, v.15, 563-568.

Sun, W., Sanderson, E., Zheng, W. (2016). Drug combination therapy increase successful drug repositioning. Drug Discov Today, 21(7), 1189-1195. 
Research, Society and Development, v. 10, n. 11, e391101119755, 2021

(CC BY 4.0) | ISSN 2525-3409 | DOI: http://dx.doi.org/10.33448/rsd-v10i11.19755

Torchilin, V. (2007). Micellar nanocarriers: pharmaceutical perspectives. Pharm Res, 24, 1-16.

Torchilin, V. (2005). Recent advances with liposomes as pharmaceutical carriers. Nat Rev Drug Discov, v.4, 145-160.

Vanicet, Ž., Rukavina, Z., Manner, S., Fallarero, A., Uzelac, L., Kraji, M., Klaric, D. A., Bogdanov, A., Raffai, T., Virok, D. D., Filipovic-Grcic, J., SkalkoBasnet, N. (2019). Azithromycin-liposomes as a novel approach for localized therapy of cervico vaginal bacterial infections. Int J Nanomedicine, 14, 59575976

Vianna, G. Tratamento da leishmaniose tegumentar por injeções intravenosas de tártaro emético.(1912). In: 7 Congresso Brasileiro de Medicina Tropical de São Paulo,4, 426-428.

Webb, M. S., Boman, N. L., Wiseman, D. J., et al. (1998). Antimicrobial efficacy against in vivo Salmonella typhimurium infection model and pharmacokinetics of a liposomal ciprofloxacin formulation. Antimicrob Agents Chemother, 42, 45-52.

Whitesides, G. M. (2003) The 'Right' Size in Nanobiotechnology. Nat Biotechnol,

$21,1161-1165$.

Zhang, X., Liu, J., Qiao, H., Liu, H., Ni, J., Zhang, W., Shi, Y. (2010). Formulation optimization of dihydroartemisinin nanostructured lipid carrier using response surface methodology. Powder Technol, 197, 120-128.

Zhang, C., Li, S., Ji, L., Liu, S., Li, Z., Li, S., Meng, X. (2015). Design, synthesis and antitumor activity of non-comptothecin topo isomerase I inhibitors. Bioorg Med Chem Lett, 25, 4693-4696. 